\title{
MicroRNA manipulation in colorectal cancer cells: from laboratory to clinical application
}

\author{
Muhammad Imran Aslam ${ }^{1,2^{*}}$, Maleene Patel ${ }^{1,2}$, Baljit Singh ${ }^{1,2}$, John Stuart Jameson ${ }^{2}$ and James Howard Pringle ${ }^{1,2}$
}

\begin{abstract}
The development of Colorectal Cancer (CRC) follows a sequential progression from adenoma to the carcinoma. Therefore, opportunities exist to interfere with the natural course of disease development and progression. Dysregulation of microRNAs (miRNAs) in cancer cells indirectly results in higher levels of messenger RNA (mRNA) specific to tumour promoter genes or tumour suppressor genes. This narrative review aims to provide a comprehensive review of the literature about the manipulation of oncogenic or tumour suppressor miRNAs in colorectal cancer cells for the purpose of development of anticancer therapies. A literature search identified studies describing manipulation of miRNAs in colorectal cancer cells in vivo and in vitro. Studies were also included to provide an update on the role of miRNAs in CRC development, progression and diagnosis. Strategy based on restoration of silenced miRNAs or inhibition of over expressed miRNAs has opened a new area of research in cancer therapy. In this review article different techniques for miRNA manipulation are reviewed and their utility for colorectal cancer therapy has been discussed in detail. Restoration of normal equilibrium for cancer related miRNAs can result in inhibition of tumour growth, apoptosis, blocking of invasion, angiogenesis and metastasis. Furthermore, drug resistant cancer cells can be turned into drug sensitive cells on alteration of specific miRNAs in cancer cells. MiRNA modulation in cancer cells holds great potential to replace current anticancer therapies. However, further work is needed on tissue specific delivery systems and strategies to avoid side effects.
\end{abstract}

Keywords: Antisense, CRC, Oligonucleotide, LNA, MicroRNA, miRNA-sponges, miR-mask

\section{Background}

Colorectal cancer (CRC) is the third most common neoplasm worldwide. According to the International Agency for Research on Cancer, approximately 1.24 million new cases of CRC were detected worldwide in 2008 [1]. The incidence of CRC is on the rise in developing countries, southern and eastern Europe [2-4]. Contrary to the current trend in Europe, the incidence of CRC in the USA has fallen in the last two decades [5]. The lifetime risk for developing CRC [6] in men is 1 in 16 whereas in women it is 1 in 20 (National Statistics, UK). The development of CRC follows the sequential progression from adenoma to carcinoma [7]. The initial genetic alteration results in adenoma formation in which cells exhibit

\footnotetext{
* Correspondence: mia7@leicester.ac.uk

'Department of Cancer Studies and Molecular Medicine, University of Leicester, Robert Kilpatrick Clinical Sciences Building, Leicester Royal Infirmary, P O Box 65, Leicester LE2 7LX, United Kingdom

${ }^{2}$ Department of Colorectal Surgery, University Hospitals of Leicester Leicester NHS Trusts, Leicester General Hospital, Gwendolen Road, Leicester LE5 4PW, United Kingdom
}

\section{Biomed Central}

(c) 2012 Aslam et al.; licensee BioMed Central Ltd. This is an Open Access article distributed under the terms of the Creative Commons Attribution License (http://creativecommons.org/licenses/by/2.0), which permits unrestricted use, distribution, and reproduction in any medium, provided the original work is properly cited. cinogenesis, intestinal epithelial cells acquire the characteristics of invasion and potential for metastasis. Therefore opportunities exist to interfere with the natural course of disease development and improve cancer specific survival. Such therapeutic interferences can potentially be chemo preventive for high risk individuals, the early detection of colorectal neoplasia, chemotherapies to down stage the surgically resected or resectable cancers, and therapies for palliation of symptoms in advanced stage cancer. Discovery of microRNAs (miRNAs) and their utility in RNA interference has opened a new era of cancer research and potential of new therapies for cancer treatment. This narrative review aims to provide a comprehensive review of the literature about the manipulation of miRNAs in colorectal cancer cells and tissue for the purpose of development of anticancer therapies. Principles of miRNA manipulation and common methods of modulation in vitro and vivo are discussed in detail for the general understanding of readers. 
This review also aims to provide the update on the role of miRNAs in CRC development and the diagnostic utility of circulating miRNAs

\section{Methods}

A search was performed using Medline, PubMed and The Cochrane Library databases from 2000 to 2011 to identify articles reporting the role of miRNAs in colorectal cancer development, diagnosis and therapy. The following $\mathrm{MeSH}$ search headings were used: 'microRNA' and 'colorectal cancer'. The search was further extended by using the following text words and their combinations: 'microRNA', 'blood,' 'circulation,' 'diagnosis,' 'screening,' 'therapy', 'manipulation,' 'modulation,' 'stem cells' and 'miRNAs'. 'The related articles' function in PubMed was used to broaden the search. All the abstracts, studies and citations found were reviewed. The most recent date of the search was 16 July 2011. Information about colorectal cancer related miRNAs was extracted on the following areas: cancer development \& progression; diagnostic utility; manipulation in vitro and vivo; development of therapies. Detailed information was extracted from studies that met the inclusion criteria: Studies conducted on human and non-human cells or tissues; blood-based miRNAs- in colorectal cancers and studies published in the English literature. Because of the lack of randomized controlled trials and the heterogeneous nature of the available data, no attempt was made to perform quantitative meta-analyses. In the absence of standard criteria for the quality assessment of laboratory-based, observational studies on miRNA and heterogeneity of outcome measures included in this narrative review, no quality assessment of included studies was carried out. As the study is only a narrative review, no ethical permission or approval was required.

\section{Results}

The literature search identified 48 original scientific studies and review articles in which some or all of the outcomes of interest were reported. 18 additional articles and web-based information sites were selected to provide a general background to miRNA and colorectal neoplasia. 36 additional studies were included to supplement the information in colorectal cancer development, detection of circulating miRNAs, and principles of miRNA therapy, design and delivery. This article provides a comprehensive review of the different approaches for restoration of tumour suppressor miRNAs expression and methods of knocking down the tumour promoter miRNAs in cancer cells. Not all the methodologies of miRNA manipulation have been applied to CRC cells and some have been experimented only on other solid organ cancers. As description and elaboration of these methods might provide an insight to future CRC therapies designed on miRNA manipulations, the authors have included principle studies focussing on mechanisms of such manipulation.

\section{Discussion}

\section{MiRNA biogenesis and function}

miRNAs are single-stranded, evolutionarily conserved, small (17-25 ribonucleotides) noncoding [8] RNA molecules. MiRNAs function as negative regulators of target genes by directing specific messenger RNA cleavage or translational inhibition through RNA induced silencing complex termed as RISC $[9,10]$. So far around fourteen hundred mature human miRNAs have been described in the Sanger miRBase version 17 (An international registry and database for miRNAs nomenclature, targets, functions and their implications in different diseases). Figure 1 illustrates the biogenesis and mechanism of action of miRNAs [11-18].

\section{MiRNAs and colorectal cancer carcinogenesis}

MiRNAs play an important role in colorectal tumour biology including; oncogenesis; progression; invasion; metastasis and angiogenesis [19-22]. Initiation and progression of colorectal neoplasia results from sequential accumulation of genetic alterations in oncogenic and tumour suppressor genes in colonic epithelium [23]. MiRNAs interfere with these genetic mutations and are involved in different stages of cancer of colorectal neoplasia. Slaby and colleagues summarized the role of different miRNAs in the development of colorectal cancer and emphasized the importance of Adenomatous Polyposis Coli (APC), Tumour Protein 53 (TP53) gene mutations and the WNT signalling Pathway [24]. The initiation of colonic neoplasia is strongly linked to inactivation of the APC gene and activation of the WNT Signalling Pathway. APC inactivation has been found in more than $60 \%$ of colonic tumours and such inactivation is associated with up regulation of $\mathrm{miR}-135 \mathrm{a} / \mathrm{b}$ in colonic epithelial cells $[23,25,26]$. Accumulation of any further somatic mutations leads to further dysregulation of miRNAs and activation of additional downstream pathways. For example let-7, miR$18 \mathrm{a}^{*}$ \& miR-143 are strongly linked to KRAS knockdown and activation of the EGFR-MAPK pathway [27-29] whereas miR-21 and miR-126 are associated with augmentation or inactivation of the phosphatidylinositol-3-kinase (PI-3-K) pathway repectively [30,31]. Activation of these downstream pathways results in autonomous tumour cell growth, increased cell survival, and initiation of angiogenesis. Loss of P53 is a critical step in transformation of adenoma to adenocarcinoma as nearly $50-70 \%$ of colonic adenocarcinomas are found to be P53 mutant [23]. miR$34 \mathrm{a}$ has been identified as a direct downstream target of P53 and the replacement of miR-34a has achieved p53 induced effects of apoptosis and cell cycle arrest [32]. A commonly up regulated miR-17-92 cluster (miR-17, miR- 


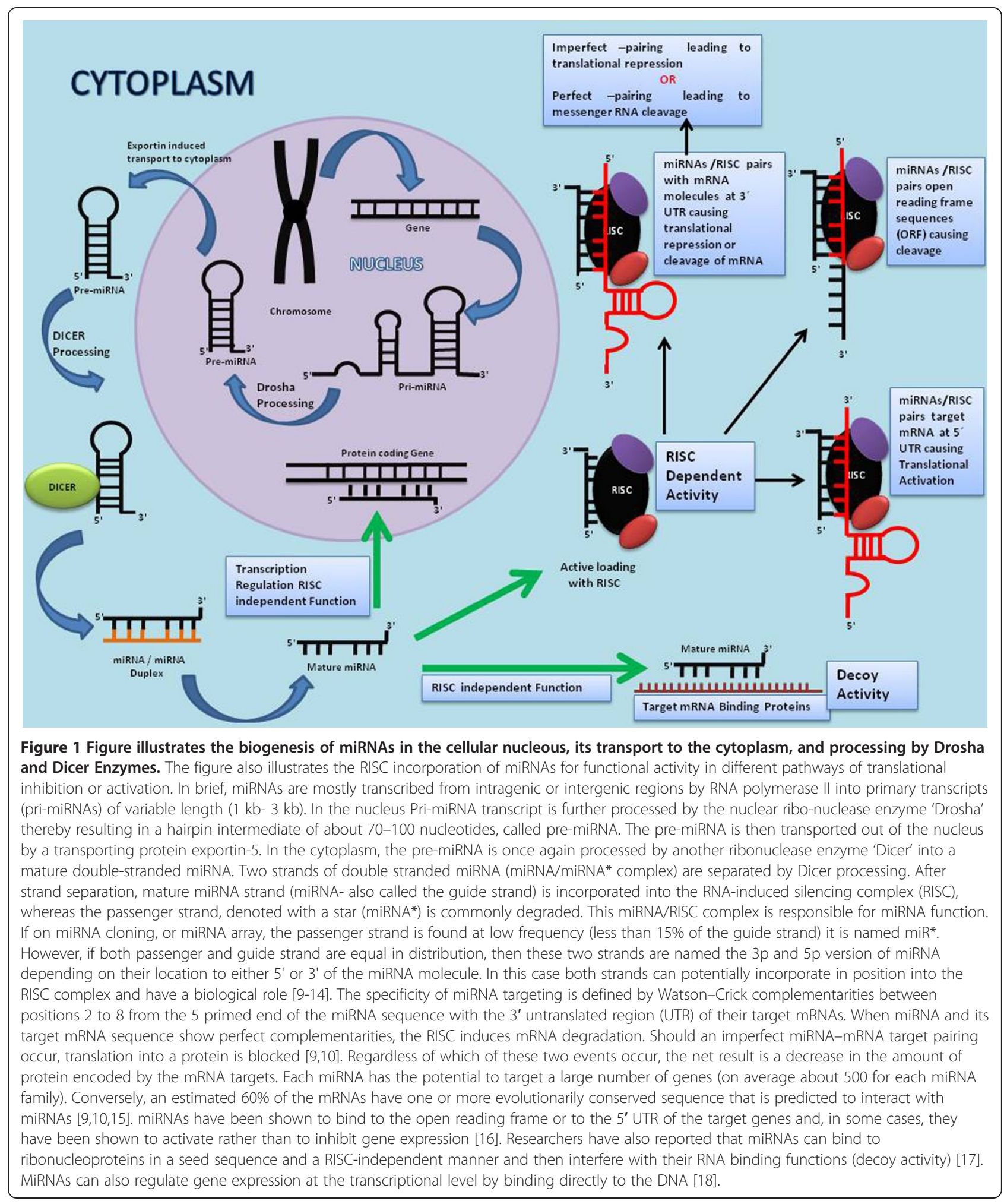

18a, miR-19a, miR-20a, miR-19b \& miR-92a) also drives the progression of adenoma to adenocarcinoma by up regulation of c-myc [33]. Figure 2 summarises the interaction of different miRNAs in signalling pathways for colorectal cancer development and progression.In the KEGG pathway, it shows the interaction of different miRNAs in the formation of adenoma and its progression to adenocarcinoma. 


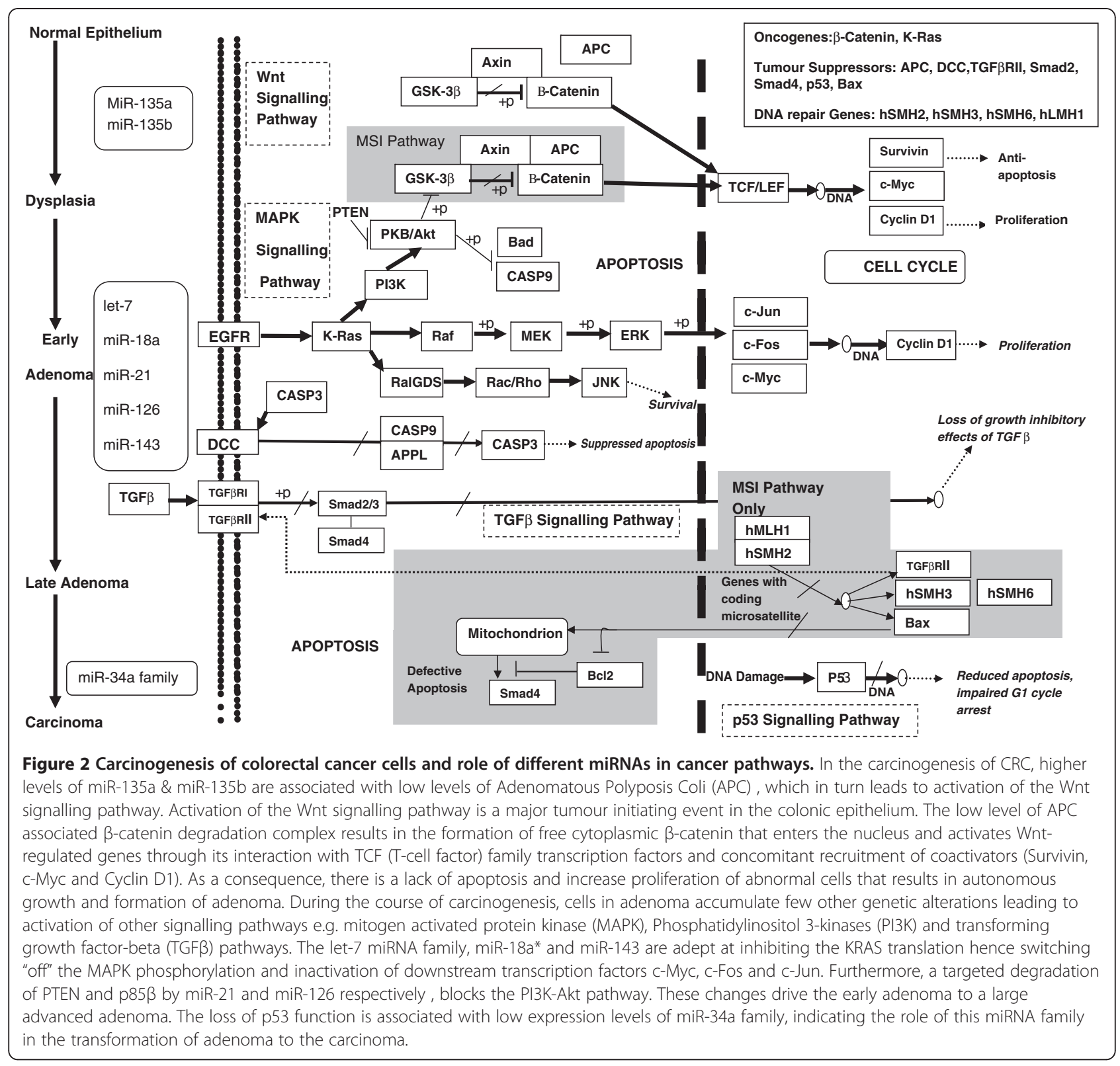

Another cancer pathway- the second serrated neoplasia pathway has recently gained acceptance and is for the most part, APC and TP53 mutation independent. It involves distinct molecular features of somatic BRAF mutation concordance with high $\mathrm{CpG}$ islands methylation phenotype (CIMP-H) and microsatellite instability (MSI+) associated with mutt homologue 1 (MLH1) methylation [34,35]. Involvement of the miRNAs in the latter pathway is slowly emerging and would require further functional studies to find the link of miRNAs associated with this pathway.

Functional and mechanistic studies of miRNAs have shown that the replacement or knockdown of distinct miRNAs in vitro resulted in distinct cytogenetic abnormalities leading to either tumour cell proliferation or apoptosis
[20]. That's why it is believed that dysregulation of miRNA genes that target mRNAs for tumour suppressor or oncogenes contributes to tumour formation by inducing cell proliferation, invasion, angiogenesis and decreased cell death [19]. This has further lead to belief that over expressed miRNAs in tumour cells function by inhibiting different tumour suppressor genes whereas miRNAs that are often found silenced in tumour cells downregulate the expression of oncogenes in normal tissue (Figures 3 \& 4). Amplification, translocation, pleomorphism or mutation in miRNA transcribing genes results in over production of miRNAs. In contrast, mutation, deletion, promoter methylation or any abnormalities in the miRNA biogenesis results in silencing of miRNAs in tumour cells [19]. Table 1 


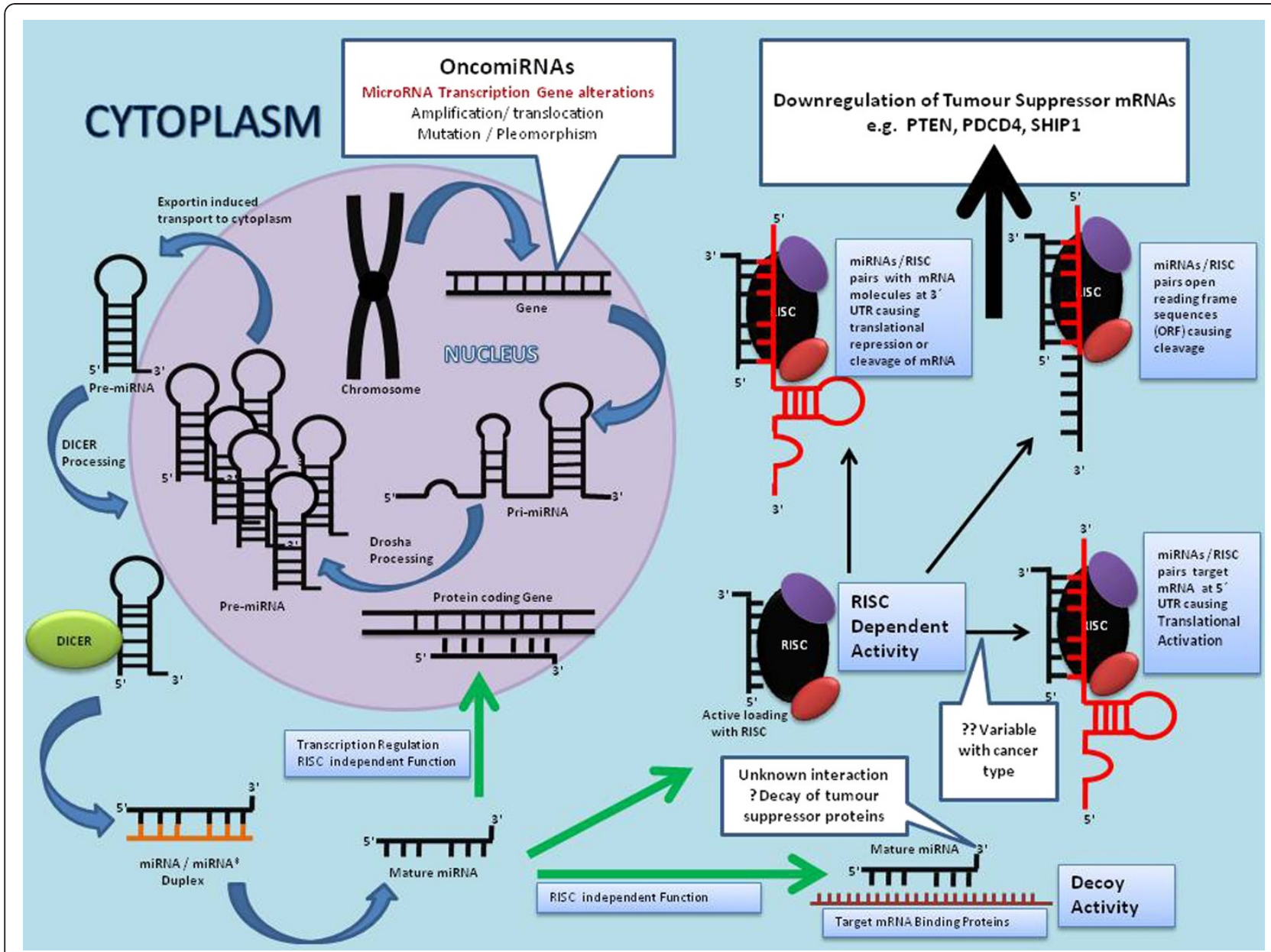

Figure 3 Figure illustrates the mechanism of biogenesis and function of OncomiRNAs. Amplification, translocation, mutation or pleomorphism in miRNA transcribing genes results in over production of pri-miRNA and pre-miRNAs in the nucleous. Further processing by the DICER results in higher levels of mature miRNAs in the cytoplasm. These overexpressed miRNAs target tumour suppressor mRNAs in the cytoplasm and lead to the downregulation of mRNAs.

summarizes commonly expressed miRNAs in colorectal cancer tissue in comparison to adjacent healthy colonic mucosa [36-49].

\section{Diagnostic utility of circulating miRNAs}

Recent studies have shown that tumour-derived miRNAs are present in human body fluids in a remarkably stable form and are protected from endogenous ribonuclease activity. In three different studies researchers have evaluated the suitability of circulating miRNAs as a diagnostic biomarker for CRC [50]. Preliminary studies suggest that CRC derived miRNAs are present in the circulation at detectable levels [51-54] and can accurately distinguish healthy controls from patients with CRC (Table 2). Significantly high sensitivity and specificity for detection of CRC holds promise for the use of circulating miRNAs as a diagnostic biomarker for CRC. Furthermore, the ability of a miRNA based blood assay to detect colonic adenoma can lead to its use in early detection and bowel cancer screening.
Although a small number of studies have identified circulating miRNAs in CRC patients, the clinical utility of this is still questionable. This is due to an overlapping miRNA expression with other solid organ cancers and benign colonic diseases, and variability of individual miRNA expression with tumour site \& stage. It is possible that the utility of tumour tissue specific expression-signature/profile may prove more informative and accurate in future clinical studies. Furthermore, the discovery of exosome mediated transport of miRNAs into the circulation, has shifted the focus of miRNA studies towards the isolation of tissue specific circulating exosomes and their contained miRNAs [55].

\section{Principles of miRNA therapy}

The fact that miRNAs regulate multiple genes in a molecular pathway, makes them excellent candidates for gene therapy. One of the most appealing properties of miRNAs as therapeutic agents is their ability to target multiple 


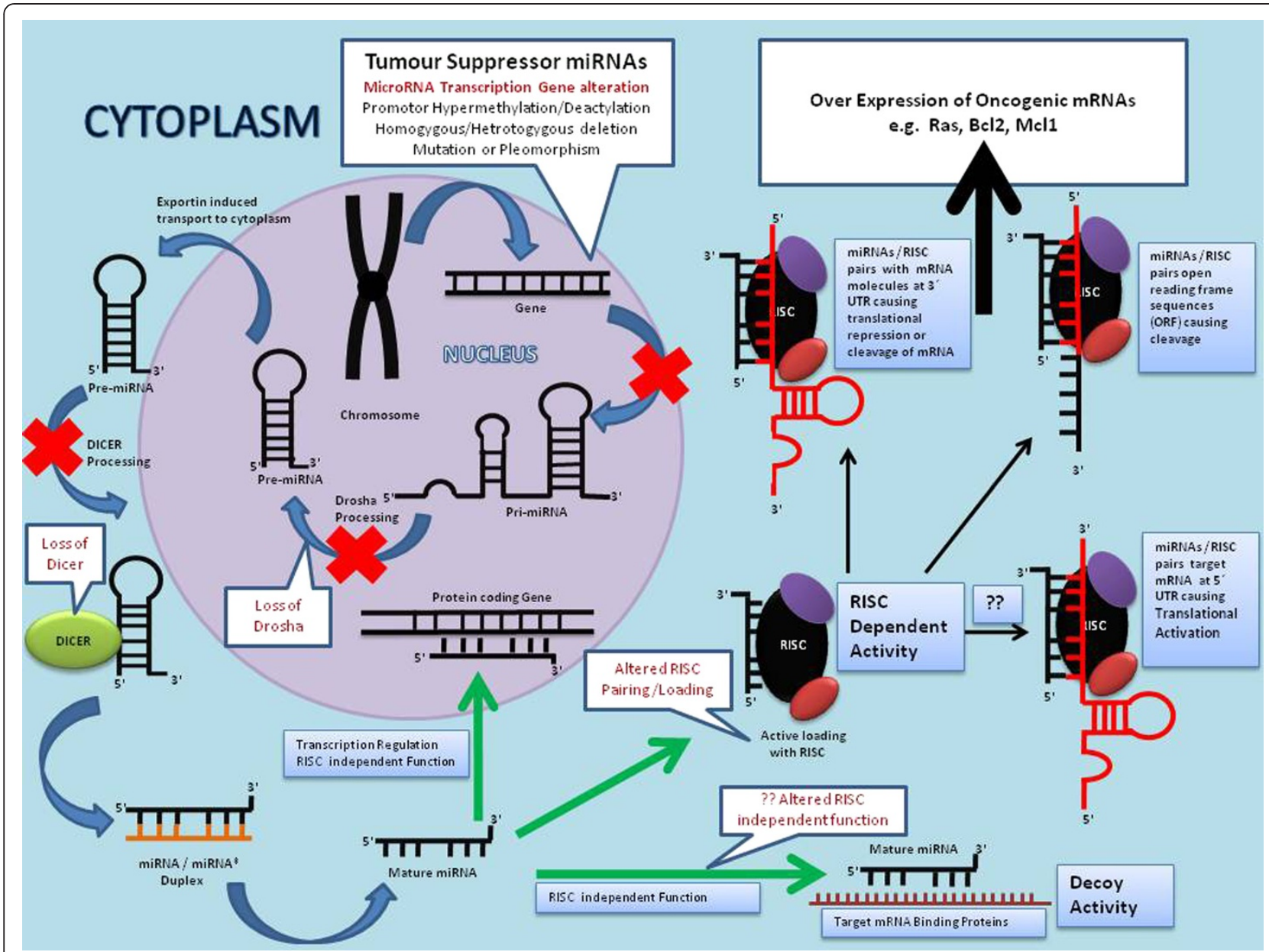

Figure 4 Figure shows the proposed mechanism of biogenesis and function of tumour suppressor miRNAs. Promotor hypermethylation/ deactylation, homogygous/hetrotogygous deletion, mutation or pleomorphism in miRNA transcription gene results in under production or complete loss of pri-miRNAs. Defects in miRNA processing machinery i.e. ineffective processing by Drosha/Dicer or defective pairing with RISC can result into inefficient levels of mature miRNAs in the cytoplasm. Low levels of tumour suppressor miRNAs result in over expression of oncogenic mRNAs (Ras, BCl2, Mcl1).

genes, frequently in the context of a network, making them extremely efficient in regulating distinct biological cell processes relevant to normal and malignant cell homeostasis. The rationale for using miRNAs as anticancer drugs is based on two major principles:

1. MiRNA expression is deregulated in cancer compared with normal tissues

2. Cancer phenotype can be changed by targeting miRNA expression

MiRNA based gene therapy is based on these two principles where manipulation of miRNA expression levels in cancer tissue results in inhibition of tumour growth, apoptosis, blocking of invasion, angiogenesis and metastasis. Restoration of the normal equilibrium for cancer related miRNA expression levels can result in growth retardation and reduced cell viability both in vivo and in vitro experiments. The major obstacle in gene therapy is the safe delivery to specific target tissue without side effects. Rapid degradation by body nucleases and poor cellular uptake owing to the unfavourable chemical structure of synthetic miRNAs have forced researchers to try chemical modifications of synthetic oligonucleotides as well as a more effective means of delivery. To overcome these delivery hurdles, viral and non-viral strategies have been developed. Restoration of tumour-suppressor miRNAs in cancer cells is usually achieved in vitro by using adenovirus-associated vectors (AAV). These vectors do not integrate into the genome and are eliminated efficiently with minimal toxicity. There are multiple AAV serotypes available, allowing for the efficient targeting of specific tissues including colorectal tissue. The ability of miRNAs to regulate several genes, does create potential problem in terms of side effects. This is a major concern in miRNA therapeutics as such interactions may lead to 
Table 1 Summary of dysregulated miRNAs in CRC compared to adjacent normal mucosa

\begin{tabular}{|c|c|c|}
\hline Studies & Downredulated miRNAs in CRC tissue & Upregulated miRNAs in CRC tissue \\
\hline Michael, et al, 2003[36] & $\begin{array}{l}\text { let-7, miR-16, miR-24, miR-26a, miR-102, miR- } \\
\text { 143, miR-145, miR-200b }\end{array}$ & \\
\hline Volinia, et al, 2006 [37] & let-7a-1, miR-9-3, miR-23b, miR-138, miR-218 & $\begin{array}{l}\text { miR-16, miR-17-5p, miR-20a, miR-21, miR-29b } \\
\text { 199a }\end{array}$ \\
\hline$X i$, et al, 2006 [32] & $\begin{array}{l}\text { let-7b, let-7 ga, miR-26a, } \\
\text { 132, miR-181a, miR-181ba }, \frac{m-3 p}{m i R-296, ~ m i R-320, ~} \\
\text { miR-372 }\end{array}$ & 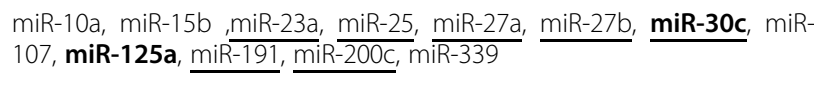 \\
\hline Bandrés, et al, 2006 [38] & miR-133b, miR-145 & 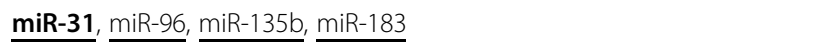 \\
\hline Akao, et al, $2006[27,39]$ & $\underline{\text { miR-143, miR-145, let7 }}$ & \\
\hline Nakajima, et al,2006 [40] & & let-7 g, miR-181b, miR-200c \\
\hline Lanza, et al, 2007 [41] & & $\underline{\operatorname{miR}-17-5 p}, \underline{m i R-20}, \underline{m i R-25}, \underline{m i R-92}, \underline{m i R-93-1}, \underline{m i R-106 a}$ \\
\hline Rossi, et al, 2007 [42] & $\underline{\mathrm{miR}-200 \mathrm{~b}}, \mathrm{miR}-210$, miR-224 & 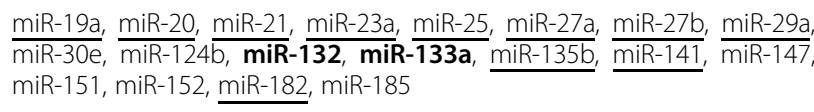 \\
\hline Monz, et al, 2008 [43] & $\underline{\mathrm{miR}-145}$ & $\underline{\text { miR-17-5p }}, \underline{\text { miR-21 }}, \underline{\text { miR-30c}}$ miR-106a, miR-107, miR-191, miR-221 \\
\hline Schepeler, et al, 2008 [44] & miR-101, miR-145, miR-455, miR-484 & miR-20a, miR-92, miR-510, miR-513 \\
\hline Schetter, et al, 2008 [45] & & $\underline{\text { miR-20a, }} \underline{\text { miR-21 }}$, $\underline{\text { miR-106a }}, \underline{\text { miR-181b}}$, miR-203 \\
\hline Arndt, et al, 2009 [46] & $\begin{array}{l}\text { miR-1, miR-10b, miR-30a-3p, miR-30a-5p, } \\
\text { miR-30c, miR-125a, miR-133a, miR-139, } \\
\text { miR-143, miR-145, miR-195, miR-378*, } \\
\text { miR-422a, } \frac{\text { miR-422b, miR-497 }}{}\end{array}$ & 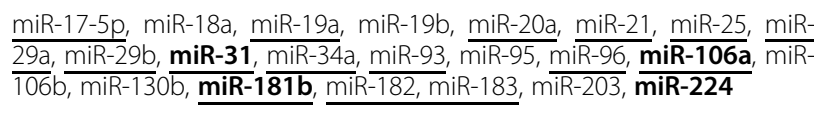 \\
\hline Slattery, et al, 2011 [47] & 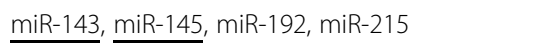 & $\underline{\text { miR-21, }}$ miR-21* \\
\hline
\end{tabular}
*Over expressed or under expressed miRNAs identified by two or more than two studies are underlined whereas the miRNAs with conflicting expression levels in different studies are identified in Bold.

toxic phenotypes formation in targeted cells [56]. This has been approached by using nano-particles and tissue specific non viral vectors. However, the concentration dependent knockdown of non specific targets still remains an unresolved issue. This article provides a comprehensive review of the different approaches for restoration of tumour suppressor miRNAs expression and methods of knocking down the tumour promoter miRNAs in cancer cells. Not all the methodologies mentioned in this article have been applied to CRC cells, but all have been investigated as a therapy for other cancers. The description and elaboration of these methods may provide an insight to miRNA therapies in CRC.

\section{Blocking oncogenic MiRNAs using antisense oligonucleotides}

The demonstration that oncogenic miRNAs are upregulated in cancer provided a rationale to investigate the

Table 2 Summary of sensitivity and specificity of different diagnostic circulating miRNAs

\begin{tabular}{|c|c|c|c|c|c|}
\hline \multirow[t]{2}{*}{ Tissue type } & \multirow[t]{2}{*}{ Studies } & \multirow[t]{2}{*}{ Participants } & \multirow{2}{*}{$\begin{array}{l}\text { Target } \\
\text { MiRNAs }\end{array}$} & \multicolumn{2}{|c|}{ Diagnostic accuracy } \\
\hline & & & & Sensitivity\% & Specificity\% \\
\hline \multirow[t]{2}{*}{ Whole Plasma } & Pu, et al, 2010 [51] & $C R C(n=103)$ & miR-221 & 86 & 41 \\
\hline & & Controls $(n=37)$ & & & \\
\hline \multirow[t]{2}{*}{ Plasma } & Cheng, et al, 2011 [52] & CRC I-IV $(n=102)$ & miR-141 & 66.7 & 80.8 \\
\hline & & Controls $(n=48)$ & & & \\
\hline \multirow[t]{6}{*}{ RNA } & Ng, et al, 2009 [53] & $C R C(n=90)$ & miR-17-3p & 64 & 70 \\
\hline & & Controls $(n=40)$ & miR-92 & 89 & 70 \\
\hline & Huang, et al, 2010 [54] & $C R C(n=100)$ & miR-29 & 69 & 89.1 \\
\hline & & Adenomas* $(n=37)$ & & $62.2^{*}$ & $84.7^{*}$ \\
\hline & & & miR-92a & 84 & 71 \\
\hline & & Controls $(n=59)$ & & $64.9^{*}$ & $81.4^{*}$ \\
\hline
\end{tabular}

*Adenoma cases. 
use of antisense oligonucleotides to block their expression. Antisense oligonucleotides work as competitive inhibitors of miRNAs, presumably by annealing to the mature miRNA guide strand and inducing degradation of mature miRNAs (Figure 5). The stability, and specificity for target miRNAs and the binding affinity of antisense oligonucleotides has been optimised by modifications to the chemical structure of the oligonucleotides [57]. In particular the introduction of 2'-O-methyl or 2'-O-methoxyethyl groups to oligonucleotides enhances resistance to nuclease enzyme and improves the binding affinities to RNA [58]. The silencing of endogenous miRNAs by this novel method has shown to be long lasting, specific and efficient both in vitro $[59,60]$ and in vivo. In CRC cells lines, antimiR based blockage of oncogenic miRNAs (miR-20a, miR-21, miR-31, miR-95, miR-672) has not only shown to reduce cell proliferation, transformation and migration, but it has resulted in enhanced sensitivity to chemotherapy agents [61-66]. This strategy of sensitizing the chemotherapy resistant tumour cells with alteration of miRNA expression in tumour cells may result in improved response to traditional chemotherapy agents. Table 3 summarizes the studies manipulating the oncogenic miRNAs in colorectal cell lines.

\section{Blocking oncogenic MiRNAs using locked nucleic acid (LNA) Constructs}

LNA construct based anti-miR therapeutic strategy has been extensively explored by researchers studying the miRNA based antiviral therapy for chronic hepatitis-C [66]. LNA nucleosides are a class of nucleic acid analogues in which the ribose ring is 'locked' by a methylene bridge connecting the $2^{\prime}-\mathrm{O}$ atom and the $4{ }^{\prime}-\mathrm{C}$ atom. By locking the molecule with the methylene bridge, LNA oligonucleotides display unprecedented hybridization

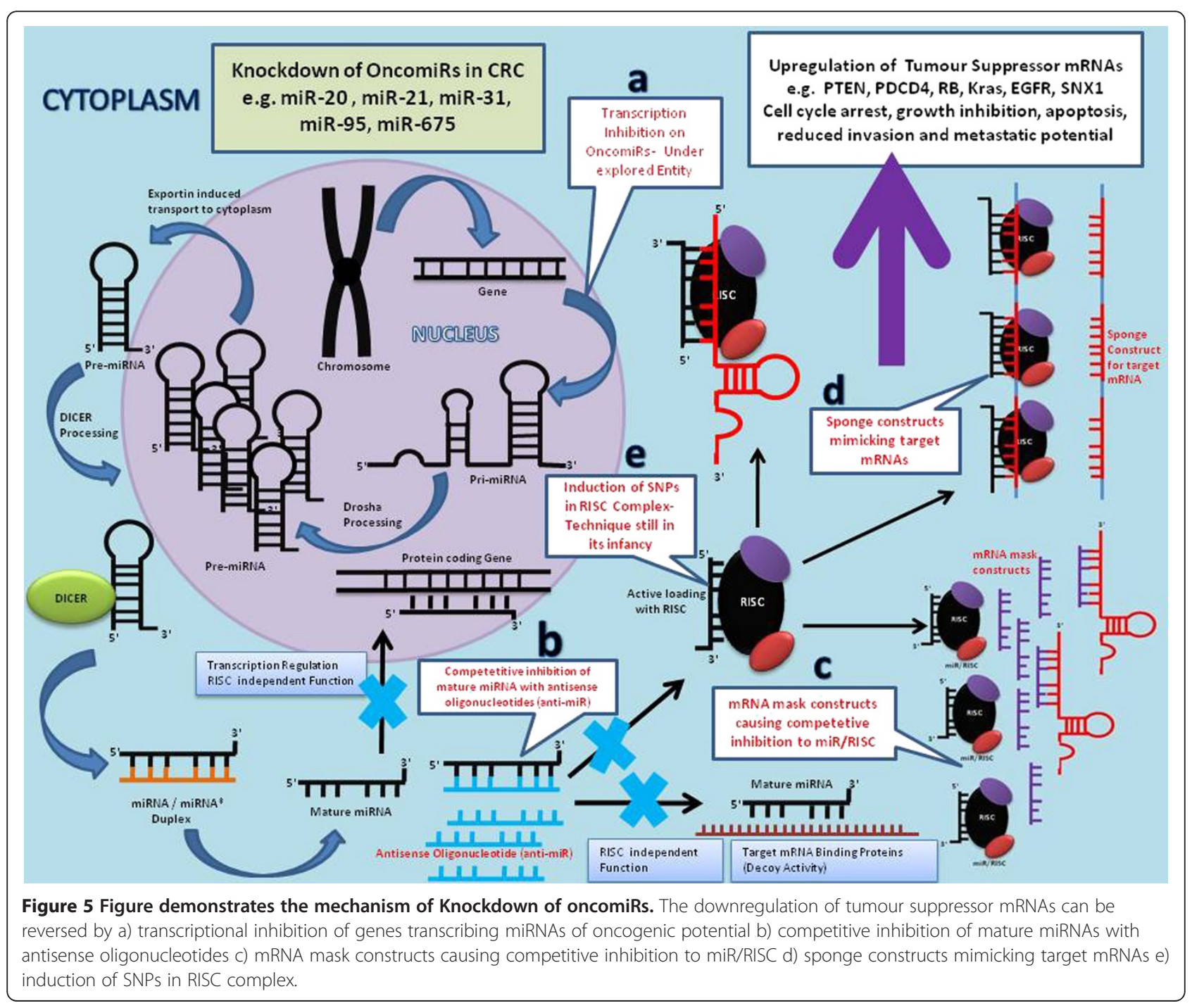


Table 3 Summary of in vitro effects of antisense oligonucleotides and locked nucleic acid based oncogenic miRNA manipulation in colorectal cell lines

\begin{tabular}{|c|c|c|c|c|c|}
\hline miRNA & Cell line & Target & Method & Reported effects of miRNA manipulation & References \\
\hline \multicolumn{6}{|c|}{ antisense oligonucleotides } \\
\hline \multirow[t]{2}{*}{ miR-20a } & SW480 & \multirow[t]{2}{*}{ BNIP2 } & \multirow[t]{2}{*}{ anti-miR-20a } & \multirow{2}{*}{$\begin{array}{l}\text { Increased sensitivity to fluorouracil, oxaliplatin, } \\
\text { and teniposide }\end{array}$} & \multirow[t]{2}{*}{ Chai, et al, 2011[61] } \\
\hline & SW620 & & & & \\
\hline miR-21 & RKO & $\mathrm{Pdcd} 4$ & anti-miR-21 & Reduced intravasation and distal metastasis & Asangani, et al, 2008[62] \\
\hline \multirow[t]{2}{*}{ miR-31 } & HCT-116 & & anti-miR-31 & Reduced migration and increased invasion & Wang, et al, 2010[63] \\
\hline & & & & Reduced proliferation only with combined 5-FU & \\
\hline \multirow[t]{2}{*}{ miR-95 } & HCT-116 LoVo & SNX1 & anti-miR-95 & Reduces cell proliferation & Huang, et al, 2011[64] \\
\hline & & EGFR & & & \\
\hline \multirow[t]{2}{*}{ miR-675 } & $\mathrm{CaCO} 2 \mathrm{HCT} 116$ & $\mathrm{RB}$ & anti-miR-675 & Reduced cell growth and colony transformation & Tsang, et al, 2010 [65] \\
\hline & HT-29 SW480 & & & & \\
\hline \multicolumn{6}{|c|}{ Locked nucleic acid (LNA) } \\
\hline \multirow[t]{3}{*}{ miR-21 } & SW480 & hMSH2 hMSH6 & LNA anti-miR-21 & Increased sensitivity to 5-FU & Valeri, et al, 2010 [67] \\
\hline & HCT-116 & & & & \\
\hline & RKO & & & & \\
\hline
\end{tabular}

affinity towards complementary single-stranded RNA and complementary single-stranded or double-stranded DNA [68]. In addition, they display excellent mismatch discrimination and high aqueous solubility. So-called 'LNA anti-miR' constructs has been used successfully by Valeri and colleagues [67] to knock down miR-21 in colon adenocarcinoma cell lines.

\section{Blocking oncogenic MiRNAs using MiRNA sponge constructs}

miRNA sponges based techniques to manipulate oncogenic miRNAs is still in its infancy and has not been studied in detail in CRC cells. miRNA sponges are transcripts that contain multiple tandem-binding sites to a miRNA of interest and are transcribed from mammalian expression vectors. Ebert and colleagues recently reported the use of miRNA sponges in mammalian cells [69]. The authors reasoned that miRNA target sequences expressed at high levels could compete with bona fide targets in a cell for miRNA binding (Figure 5). To increase the affinity of these decoy transcripts, the researchers introduced not only multiple miRNA binding sites, but also a bulge at the position normally cleaved by argonaute 2 , therefore facilitating the stable association of miRNA sponges with ribonucleoprotein complexes loaded with the corresponding miRNA. Using these constructs, repression of miRNA targets was observed and proved effective in vitro silencing of miRNAs [69]. Theses effects were comparable with those obtained with 2'-O-methyl-modified oligonucleotides or LNA antisense oligonucleotides. Furthermore, sponges that contained only the heptameric seed were shown to effectively repress an entire miRNA family that shares by definition the same seed sequence [69].

\section{Blocking oncogenic MiRNAs using MiRNA masking antisense oligonucleotides}

MiRNA masking effect strategy is designed to target single signalling cancer pathways. miR-mask (miRNA-masking antisense oligonucleotides) technology has been developed by Xiao and colleagues [70]. In contrast to miRNA sponges, miR-masks consist of single-stranded 2'-O-methyl-modified antisense oligonucleotides that are fully complementary to predicted miRNA binding sites in the 3' UTR of the target mRNA [70]. In this way, the miR-mask covers up the miRNA-binding site to hide its target mRNA (Figure 5), thereby its effects are gene specific. This technology has been applied successfully in a zebrafish model to prevent the repressive actions of miR-430 in the transforming growth factor- $\beta$ signalling pathway [71]. Although unwanted effects or off-target effects can be dramatically reduced with this approach, this may be a disadvantage for cancer therapy in which the targeting of multiple pathways may be desirable.

\section{Blocking oncogenic MiRNAs using inhibitors of oncogenic pathways}

Several drugs may have the ability to modulate the expression of miRNAs by targeting signalling pathways that ultimately converge on the activation of transcription factors which in turn regulate miRNA encoding genes. Furthermore, it is possible to modulate the machinery that contributes to miRNA maturation and degradation processes. The identification of these compounds, however, is not straightforward and requires efficient screening of chemical libraries. Recently, Gumireddy and colleagues identified a method to screen for small-molecule inhibitors of miRNAs [72]. As a proof of concept for this 
approach, the investigators selected the frequently studied and up-regulated miRNA, miR-21. Complementary sequences to miR-21 were cloned into a luciferase reporter gene, which was then used as a sensor to detect the presence of specific mature miRNA molecules. The construct was transfected into HeLa cells, which express high miR-21 levels, resulting in low luciferase activity. Subsequently, a primary screen of more than several smallmolecule compounds was done and an initial hit compound, diazobenzene 1 , produced a $250 \%$ increase in the intensity of the luciferase signal relative to the untreated cells [72]. Additional characterization showed that this compound affects the transcription of miR-21. This strategy could be applied to the screening of small molecules as inhibitors for other distinct oncogenic miRNAs. These could be used with conventional cancer therapeutics to develop novel combined approaches for cancer treatment.

\section{Restoration of tumour-suppressor miRNAs}

The loss or downregulation of a tumour-suppressor miRNA could be overcome by introducing synthetic oligonucleotides i.e. mature miRNA mimics, miRNA precursors or pre-miRNA mimics into the CRC cells (Figure 6). Introduction of synthetic miRNAs with tumour-suppressor function in cancer cells have been shown to induce cell death and block cellular proliferation, transformation, invasion and migration in several studies as summarized in Table 4. The altered expression of tumour suppressor miRNAs have been studied in the context of cancer-associated transcription factors. P53 mutations have been found in $40-50 \%$ of CRCs. The p53 protein is a transcription factor that regulates multiple cellular processes in CRC development, either by regulating mRNA directly or by regulating miRNA indirectly. The absence of p53 mutations in adenomas suggests that loss of p53 is a critical step in progression of adenoma to carcinoma [73,74]. In addition, the miR-34 family has been strongly linked to p53 and loss of p53 has been linked to reduced levels of miR-34 in cancer cells. miR-34a restoration studies [75,76] have clearly demonstrated reduced cell survival, invasion and migration in CRC cell lines. In addition to a link with the p53 pathway, miR-34a encoding genes on their own have been identified as targets for the mutational or epigenetic inactivation in different cancers. Interestingly, miR$34 \mathrm{a}$ resides on the chromosomal locus $1 \mathrm{p} 36$, which has been proposed to harbor a tumor suppressor gene because it displays homozygous deletions in neuroblastoma and in other tumor types [77]. An unbiased screen for genes with tumor suppressive function on 1 p36 also revealed miR-34a as a candidate tumor suppressor gene [78]. Therefore miR-34 targeted gene therapies hold a prime importance in the designing therapies for chemoprevention and to halt the tumour progression. miR-143 is another tumour suppressor miRNA, significantly found downregulated in CRC tissues (Table 1). The most significant study in this respect is restoration of miR-143 with miR-143 precursor resulting in reduced proliferation in SW480 colorectal cell lines and tumour suppression on xenografted tumors of DLD-1 human CRC cells $[79,80]$. Restoration of tumour suppressor miRNA by intravenous injection in mouse with liver cancer resulted in the suppression of tumorigenicity by reduced tumour growth and enhanced tumour apoptosis without signs of toxicity. This illustrates that tumour suppressor miRNA restoration strategy based gene therapy, if delivered efficiently to specific tissues may prove vital in future cancer treatments.

\section{Modulation of miRNA processing}

Alterations in miRNA processing machinery have also been implicated in cancer development and modulation of this machinery in part or in general can potentially lead to the discovery of new anticancer therapies. Researchers have investigated the global repression of miRNA maturation process in cells and have identified that the abrogation of miRNA processing pathway promotes the cellular transformation and tumorigenesis [91]. The inhibition of Dicer1 activity on its own has also been associated with cancer development, invasion and lymph node metastasis [91-94]. Therefore, speeding up the miRNA processing globally or by replacement of Dicer1 in cancer cells can alter their progression and invasive potential. However, the effects of alterations in miRNA biogenesis pathway have found to vary for different tumour types [92,93] and therapeutic strategy will vary dependent on the response for inhibition or acceleration of miRNA processing.

\section{Cancer stem cell directed miRNA therapy}

Cancer stem cells or tumor-initiating cells have recently gained enormous attention. According to this hypothesis a subpopulation of cancer cells possesses unique characteristics of self renewal and multipotent differentiation; fundamental characteristics of embryonic and somatic stem cells [95]. As cancer stem cells or tumor-initiating cells are highly resistant to conventional chemotherapy and radiotherapy $[96,97]$ there is further need for stem cell targeted therapy. Accumulating evidence indicates that miRNAs play functional roles in normal and cancer stem cell maintenance and differentiation. MiRNA expression signatures for differentiated cells are distinctly different from embryonic and somatic stem cells $[98,99]$. However, miRNA expressions in cancer stem cells have significant similarities with embryonic and somatic stem cells. Monzo and colleagues studied the common miRNAs for CRC and embryonic tissue and suggested that the miR-17-92 cluster and its target, E2F1, exhibit a 


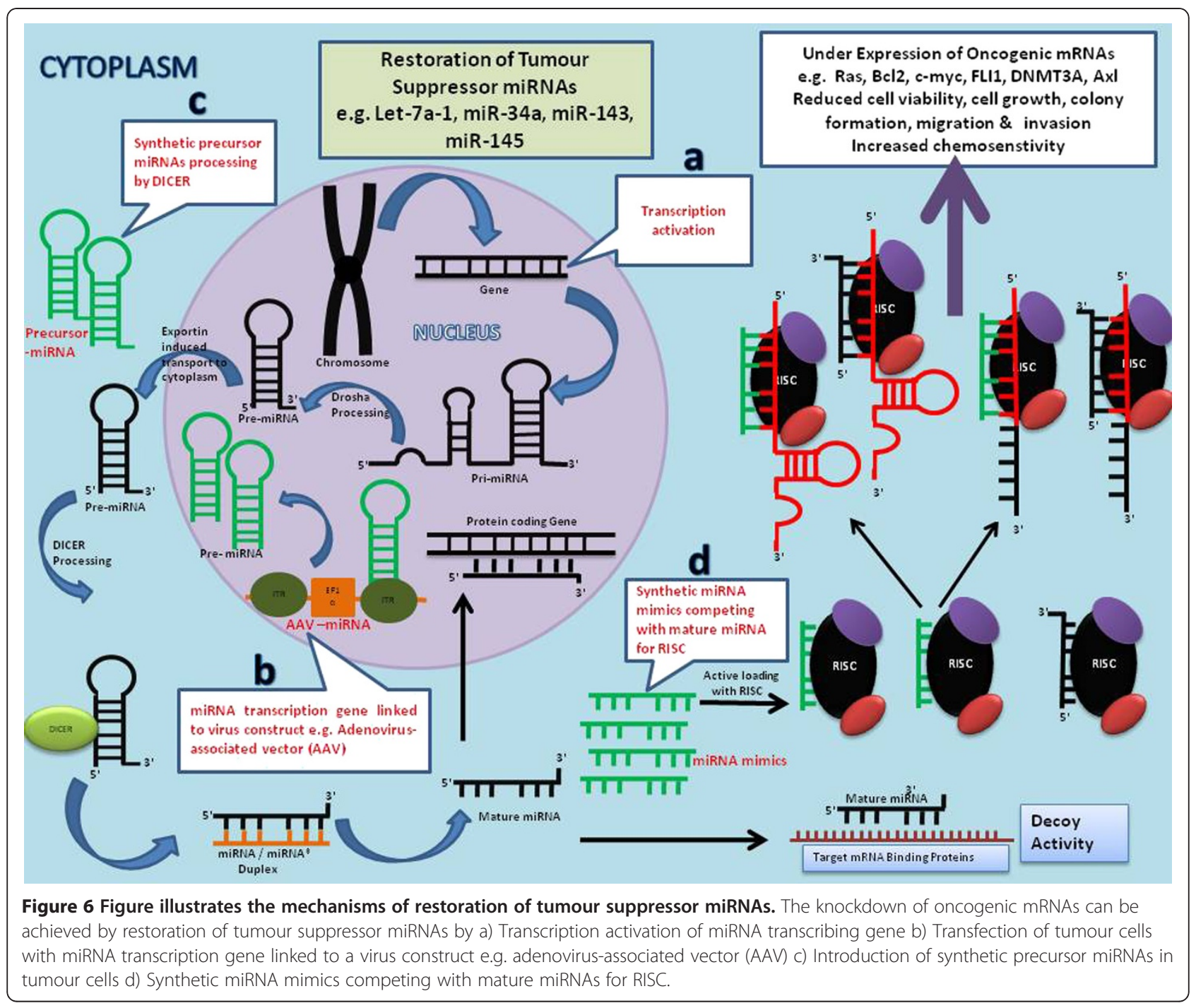

similar pattern of expression in human colon development and colonic carcinogenesis [43]. Further studies dealing with miRNA biogenesis and stem cells; have suggested that mutation of the key proteins in miRNA biogenesis pathway fail to maintain the self-renewal and differentiation capacities [99-102]. Recent studies have demonstrated the role of let-7 in self renewal, differentiation and regulation of progenitor maintenance. Low expression of let-7 in cancer stem cells and restoration of stem cell related miRNAs expression level in cancer cells might prove pivotal in treating cancers by modulating cancer stem cells.

\section{Conclusions}

In summary, there is strong evidence that miRNAs play a significant role in CRC development and progression. There is emerging evidence that miRNAs interact with different cancer signalling pathways and control cellular homeostasis. Changes in miRNAs expression levels results in alteration of this homeostasis and significantly contribute in cancer development and progression. Cancer specific miRNAs are detectable in body fluids and can potentially be used as novel biomarkers for CRC detection and prediction of cancer specific survival. MiRNAs influence oncogenic potential and therefore strategies to manipulate oncogenic or tumour suppressor miRNAs can successfully halt tumour progression. Furthermore, miRNA manipulation strategies can potentially be used as an adjuvant to other forms of anticancer therapies as miRNA manipulation can be used to sensitise drug resistant tumours. Finally, stem cell directed miRNA based therapies can be used to control stemness and latency of cancer stem cells in order to prevent the recurrence of tumour. However, miRNA based gene therapy is still in its infancy, but does hold great potential to replace current anticancer 
Table 4 Summary of studies involving the restoration of silenced miRNAs in CRC cell lines

\begin{tabular}{|c|c|c|c|c|c|}
\hline miRNAs & Cell Line & Target & Method & Reported effects of miRNA manipulation & References \\
\hline \multirow[t]{2}{*}{ let-7a-1 } & DLD-1 & Ras & \multirow[t]{2}{*}{ let-7a-1 precursor } & \multirow{2}{*}{$\begin{array}{l}\text { Reduced cell viability, cell growth and } \\
\text { colony formation }\end{array}$} & \multirow[t]{2}{*}{ Akao, et al, 2006 [27] } \\
\hline & SW480 & $c-m y c$ & & & \\
\hline \multirow[t]{2}{*}{ miR-34a } & \multirow[t]{2}{*}{ DLD-1 } & Sirt1 & \multirow[t]{2}{*}{ miR-34a mimic } & Reduced cell growth & \multirow[t]{2}{*}{ Akao, et al, $2011[75]$} \\
\hline & & E2F3 & & Enhanced sensitivity to 5-FU & \\
\hline miR-34a & Rko & $A \times l$ & pre-miR-34a & Reduced migration \& invasion & Mudduluru, et al, 2011 [76] \\
\hline miR-133b & SW-620 HT-29 & tyrosine kinase MET & miR-133b precursor & Reduces cell proliferation Increased apoptosis & $\mathrm{Hu}$, et al, 2010 [81] \\
\hline \multirow[t]{2}{*}{$\mathrm{miR}-135 \mathrm{a} / \mathrm{b}$} & CLY & \multirow[t]{2}{*}{ CM-1 cytotoxicity } & miR-135a, & \multirow[t]{2}{*}{ Increased sensitivity to anticancer agent } & \multirow[t]{2}{*}{$\mathrm{Li}$, et al, 2011[82] } \\
\hline & HT-29 & & miR -135b mimics & & \\
\hline \multirow[t]{2}{*}{ miR-137 } & SW1116, & \multirow[t]{2}{*}{ Cdc42 } & \multirow[t]{2}{*}{ miR-137 mimic } & Reduces cell proliferation, Cell cycle arrest & \multirow[t]{2}{*}{ Liu, et al, 2011 [83] } \\
\hline & Lovo, Colo320 & & & Inhibition of invasion & \\
\hline \multirow[t]{2}{*}{ miR-143 } & SW480, & \multirow[t]{2}{*}{ DNMT3A } & \multirow[t]{2}{*}{ miR-143 precursor } & Reduces cell proliferation & \multirow[t]{2}{*}{ Ng, et al, 2009 [79] } \\
\hline & 228 & & & & \\
\hline miR-143 & DLD-1 & & miR-143 precursor & $\begin{array}{l}\text { tumor-suppressive effect on xenografted } \\
\text { tumors of DLD-1 human CRC cells }\end{array}$ & Nakagawa, et al, 2010 [80] \\
\hline \multirow[t]{2}{*}{ miR-145 } & LS174T & \multirow[t]{2}{*}{ FLI1 } & \multirow[t]{2}{*}{ miR-145 precursor } & \multirow[t]{2}{*}{ Reduces cell proliferation and colony formation } & \multirow[t]{2}{*}{ Zhang, et al, 2011 [84] } \\
\hline & SW620 HCT116 & & & & \\
\hline \multirow[t]{2}{*}{ miR145 } & HCT116 & \multirow[t]{2}{*}{ IRS-1 } & \multirow[t]{2}{*}{ ds-oligos miR145 } & \multirow[t]{2}{*}{ Reduces cell proliferation } & \multirow[t]{2}{*}{ Shi , et al, 2007 [85] } \\
\hline & $\mathrm{KO}$ & & & & \\
\hline miR-185 & SW1116 Lovo & RhoA Cdc42 & hsa-miR-185 mimic & Cell cycle arrest \& growth suppression & Liu, et al, 2010 [86] \\
\hline miR-192 & $\begin{array}{l}\text { RKO, LoVo, } \\
\text { DLD1, SW620 }\end{array}$ & TYMS & Pre-miR-192 & Reduces cell proliferation & Boni, et al, 2010 [87] \\
\hline \multirow[t]{2}{*}{ miR-195 } & HT29 and LoVo & $\mathrm{BCl}-2$ & miR-195 mimic & Reduces cellular viability Increased apoptosis & Liu, et al, 2010 [88] \\
\hline & & & & Reduced colony formation & \\
\hline miR-196a & SW480 & HoxA7, HoxB8, & miR-196a mimics & Reduced migration, invasion & Schimanski, et al, 2009 [89] \\
\hline & & & & Increased cellular adhesion & \\
\hline & & & & $\begin{array}{l}\text { Increased sensitivity to platin derived } \\
\text { anticancer agents }\end{array}$ & \\
\hline miR-199a & Rko & Axl & pre-miR-199a & Reduced migration, invasion & Mudduluru, et al, 2011[76] \\
\hline $\operatorname{miR} 200 \mathrm{c}$ & CLY & CM-1 cytotoxicity & $\operatorname{miR} 200 c$ & Low chemosenstivity with high miR-200c & Li, et al, [82] \\
\hline & HT-29 & & mimics & & \\
\hline miR-215 & $\begin{array}{l}\text { RKO, LoVo, } \\
\text { DLD1, SW620 }\end{array}$ & TYMS & pre-miR-215 & Reduces cell proliferation & Boni, et al, 2010 [87] \\
\hline miR-491 & DLD-1 & $B C l-X L$ & miR-491 precursor & Reduces cell proliferation & Nakano, et al, 2010 [90] \\
\hline & & & & Increased apoptosis & \\
\hline
\end{tabular}

therapies. Further work is needed on an efficient, tissue specific delivery system and strategies to avoid side effects.

\section{Competing interest}

The authors declare that they have no competing interests.

\section{Authors' contribution}

MIA: literature search, review of studies, critical analysis of studies, layout of manuscript, design of figures and tables. MP: literature search, review of studies, critical analysis of studies. JHP: critical review of manuscript and analysis of the quality of manuscript. BS:, reviewed the quality of manuscript. JSJ: Review of quality, structure and design of manuscript. All authors read and approved the manuscript.
Received: 18 October 2011 Accepted: 21 February 2012

Published: 20 June 2012

\section{References}

1. Ferlay J, Shin HR, Bray F, et al: GLOBOCAN 2008, Cancer Incidence and Mortality Worldwide: IARC CancerBase No. 10., . http://globocan.iarc.fr/ factsheet.asp.

2. Coleman M, Estève J, Damiecki P, Arslan A, Renard H: Trends in Cancer Incidence and Mortality, IARC Scientific Publications, Volume 121. Lyon: IARC; 1993.

3. Ferlay J, Parkin DM, Steliarova-Foucher E: Estimates of cancer incidence and mortality in Europe in 2008. Eur J Cancer 2010, 46(4):765-781.

4. Marchand L: Combined influence of genetic and dietary factors on colorectal cancer incidence in Japanese Americans. J Natl Cancer Inst Monogr 1999, 26:101-105. 
5. Howlader N, Noone AM, Krapcho M, et al: SEER Cancer Statistics Review, 1975-2008, National Cancer Institute., . http://seer.cancer.gov/csr/ 1975_2008/

6. Bray F, Atkin W: International cancer patterns in men: geographical and temporal variations in cancer risk and the role of gender. JMHG 2004, 1 (1):38-46.

7. Vogelstein B, Fearon ER, Hamilton SR, et al: Genetic alterations during colorectal- tumor development. N Engl J Med 1988, 319(9):525-532.

8. Lee RC, Feinbaum RL, The AV: The C. elegans heterochronic gene lin-4 encodes small RNAs with antisense complementarity to lin-14. Cell 1993 75(5):843-854

9. Bartel DP: MicroRNAs: genomics, biogenesis, mechanism, and function. Cell 2004, 116(2):281-297.

10. Bartel DP: MicroRNAs: target recognition and regulatory functions. Cell 2009, 136:215-233.

11. Lee $Y$, Ahn C, Han J, et al: The nuclear RNase III Drosha initiates microRNA processing. Nature 2003, 425:415-419.

12. Bohnsack MT, Czaplinski K, Gorlich D: Exportin 5 is a RanGTP-dependent dsRNA-binding protein that mediates nuclear export of pre-miRNAs. RNA 2004, 10:185-191.

13. Thimmaiah $P$, et al: TRBP recruits the Dicer complex to Ago2 for microRNA processing and gene silencing. Nature 2005, 436:740-744.

14. Hammond S, Bernstein E, Beach D, et al: An RNA-directed nuclease mediates post-transcriptional gene silencing in Drosophila cells. Nature 2000, 404:293-296.

15. Friedman RC, Farh KK, Burge CB: Most mammalian mRNAs are conserved targets of microRNAs. Genome Res 2009, 19:92-105.

16. Ørom UA, Nielsen FN, Lund AH: MicroRNA-10a binds the 5'UTR of ribosomal protein mRNAs and enhances their translation. Mol Cell 2008, 4:460-471.

17. Eiring A, et al: miR-328 functions as an RNA decoy to modulate hnRNP E2 regulation of mRNA translation in leukemic blasts. Cell 2010, 140:652-665.

18. Khraiwesh $B$, et al: Transcriptional control of gene expression by microRNAs. Cell 2010, 140:112-122.

19. Esquela-Kerscher A, Slack FJ: Oncomirs - microRNAs with a role in cancer. Nat Rev Cancer 2006, 6(4):259-269.

20. Huang Q, Gumireddy K, Schrier M, et al: The microRNAs miR-373 and miR520c promote tumour invasion and metastasis. Nat Cell Biol 2008, 10 (2):202-210.

21. Zhang BG, Li JF, Yu BQ, et al: microRNA-21 promotes tumor proliferation and invasion in gastric cancer by targeting PTEN. Oncol Rep 2012, 27 (4):1019-1026.

22. Lee DY, Deng Z, Wang CH, et al: MicroRNA-378 promotes cell survival, tumor growth, and angiogenesis by targeting SuFu and Fus- 1 expression. Proc Natl Acad Sci U S A 2007, 104(51):20350-20355.

23. Fearon $E R$, Vogelstein B: A genetic model for colorectal tumorigenesis. Cell 1990, 61:759-767.

24. Salby O, Svoboda M, Michalek J, et al: MicroRNAs in colorectal cancer: translation of molecular biology into clinical application. Mol Cancer 2009, 14:8-102.

25. Segditsas S, Tomlinson I: Colorectal cancer and genetic alterations in the Wnt pathway. Oncogene 2006, 25(57):7531-7537.

26. Nagel R, le Sage C, Diosdado B, Waal M: Oude Vrielink JA, Bolijn A, Meijer GA, Agami R: Regulation of the adenomatous polyposis coli gene by the miR-135 family in colorectal cancer. Cancer Res 2008, 68:5795-5802.

27. Akao $Y$, Nakagawa $Y$, Naoe $T$ : let-7 microRNA functions as a potential growth suppressor in human colon cancer cells. Biol Pharm Bull 2006, 29:903-906.

28. Chen $X$, Guo X, Zhang $H$, Xiang $Y$, Chen J, Yin Y, Cai X, Wang K, Wang G, Ba Y, Zhu L, Wang J, Yang R, Zhang Y, Ren Z, Zen K, Zhang J, Zhang CY: Role of miR-143 targeting KRAS in colorectal tumorigenesis. Oncogene 2009, 28:1385-1392.

29. Tsang WP, Kwok TT: The miR-18a* microRNA functions as a potential tumor suppressor by targeting on K-Ras. Carcinogenesis 2009 30:953-959.

30. Krichevsky AM, Gabriely G: miR-21: a small multi-faceted RNA. J Cell Mol Med 2009, 13:39-53.

31. Guo C, Sah JF, Beard L, Willson JK, Markowitz SD, Guda K: The noncoding RNA, miR-126, suppresses the growth of neoplastic cells by targeting phosphatidylinositol 3-kinase signaling and is frequently lost in colon cancers. Genes Chromosomes Cancer 2008, 47:939-946.
32. Chang TC, Wentzel EA, Kent OA, et al: Transactivation of miR-34a by p53 broadly influences gene expression and promotes apoptosis. Mol Cell 2007, 26(5):745-752.

33. Diosdado B, van de Wiel MA, Terhaar Sive Droste JS: MiR-17-92 cluster is associated with $13 q$ gain and c-myc expression during colorectal adenoma to adenocarcinoma progression. Br J Cancer 2009, 101(4):707-714.

34. Spring KJ, Zhao ZZ, Karamatic R, et al: High prevalence of sessile serrated adenomas with BRAF mutations: a prospective study of patients undergoing colonoscopy. Gastroenterology 2006, 131(5):1400-1407.

35. Casey G, Lindor NM, Papadopoulos N, et al: Colon Cancer Family Registry. Conversion analysis for mutation detection in $\mathrm{MLH} 1$ and $\mathrm{MSH} 2$ in patients with colorectal cancer. JAMA 2005, 293(7):799-809.

36. Michael MZ, O' Connor SM, van Holst Pellekaan NG, et al: Reduced accumulation of specific microRNAs in colorectal neoplasia. Mol Cancer Res 2003, 12(1):882-891.

37. Volinia S, Calin GA, Liu CG, et al: A microRNA expression signature of human solid tumors defines cancer gene targets. Proc Natl Acad Sci U S A 2006, 103(7):2257-2261.

38. Bandrés $E$, Cubedo $E$, Agirre $X$, et al: Identification by Real-time PCR of 13 mature microRNAs differentially expressed in colorectal cancer and nontumoral tissues. Mol Cancer 2006, 5:29.

39. Akao Y, Nakagawa Y, Naoe T: MicroRNAs 143 and 145 are possible common onco-microRNAs in human cancers. Oncol Rep 2006, 16(4):845-850.

40. Nakajima G, Hayashi K, Xi Y, et al: Non-coding MicroRNAs hsa-let-7 g and hsa-miR-181b are Associated with hemoresponse to S-1 in Colon Cancer. Cancer Genomics Proteomics 2006, 3(5):317-324.

41. Lanza $G$, Ferracin $M$, Gafà $R$, et al: mRNA/microRNA gene expression profile in microsatellite unstable colorectal cancer. Mol Cancer 2007, 6:54.

42. Rossi L, Bonmassar E, Faraoni I: Modification of miR gene expression pattern in human colon cancer cells following exposure to 5-fluorouracil in vitro. Pharmacol Res 2007, 56(3):248-253.

43. Monzo M, Navarro A, Bandres E, et al: Overlapping expression of microRNAs in human embryonic colon and colorectal cancer. Cell Res 2008, 18(8):823-833.

44. Schepeler T, Reinert JT, Ostenfeld MS, et al: Diagnostic and prognostic microRNAs in stage II colon cancer. Cancer Res 2008, 68(15):6416-6424

45. Schetter AJ, Leung SY, Sohn JJ, et al: MicroRNA expression profiles associated with prognosis and therapeutic outcome in colon adenocarcinoma. JAMA 2008, 299(4):425-436.

46. Arndt GM, Dossey L, Cullen LM, et al: Characterization of global microRNA expression reveals oncogenic potential of miR-145 in metastatic colorectal cancer. BMC Cancer 2009, 9:374.

47. Slattery ML, Wolff E, Hoffman MD, et al: MicroRNAs and colon and rectal cancer: differential expression by tumor location and subtype. Genes Chromosomes Cancer 2011, 50(3):196-206.

48. Xi Y, Formentini A, Chien M, et al: Prognostic Values of microRNAs in Colorectal Cancer. Biomark Insights 2006, 2:113-121.

49. Slaby O, Svoboda M, Fabian P, et al: Altered expression of miR-21, miR-31, miR-143 and miR-145 is related to clinicopathologic features of colorectal cancer. Oncology 2007, 72(5-6):397-402.

50. Chen $X, B a Y, M a ~ L$, et al: Characterization of microRNAs in serum: a novel class of biomarkers for diagnosis of cancer and other diseases. Cell Res 2008, 18(10):997-1006.

51. Pu XX, Huang GL, Guo HQ, et al: Circulating miR-221 directly amplified from plasma is a potential diagnostic and prognostic marker of colorectal cancer and is correlated with p53 expression. J Gastroenterol Hepatol 2010, 25(10):1674-1680.

52. Cheng $H$, Zhang L, Cogdell DE, et al: Circulating plasma MiR-141 is a novel biomarker for metastatic colon cancer and predicts poor prognosis. PLOS One 2011, 6(3):e17745.

53. Ng EK, Chong WW, Jin H, et al: Differential expression of microRNAs in plasma of patients with colorectal cancer: a potential marker for colorectal cancer screening. Gut 2009, 58(10):1375-1381.

54. Huang $\mathrm{Z}$, Huang $\mathrm{D}, \mathrm{Ni} \mathrm{S}$, et al: Plasma microRNAs are promising novel biomarkers for early detection of colorectal cancer. Int J Cancer 2010, 127 (1):118-126.

55. Taylor DD, Gercel-Taylor C: MicroRNA signatures of tumor-derived exosomes as diagnostic biomarkers of ovarian cancer. Gynecol Oncol 2008, 110(1):13-21.

56. Dias N, Stein CA: Antisense oligonucleotides: basic concepts and mechanisms. Mol Cancer Ther 2002, 1(5):347-355. 
57. Weiler J, Hunziker J, Hall J: Anti-miRNA oligonucleotides (AMOs): ammunition to target miRNAs implicated in human disease? Gene Ther 2006, 13(6):496-502.

58. Hutvágner G, Simard MJ, Mello CC, et al: Sequence-specific inhibition of small RNA function. PLOS Bio/ 2004, 2(4):E98.

59. Mott JL, Kobayashi S, Bronk SF, et al: mir-29 regulates $\mathrm{Mcl}-1$ protein expression and apoptosis. Oncogene 2007, 26(42):6133-6140.

60. Cimmino A, Calin GA, Fabbri M, et al: miR-15 and miR-16 induce apoptosis by targeting BCL2. Proc Natl Acad Sci U S A 2005, 102(39):13944-13949.

61. Chai H, Liu M, Tian R, et al: miR-20a targets BNIP2 and contributes chemotherapeutic resistance in colorectal adenocarcinoma SW480 and SW620 cell lines. Acta Biochim Biophys Sin (Shanghai) 2011, 43(3):217-225.

62. Asangani IA, Rasheed SA, Nikolova DA, et al: MicroRNA-21 (miR-21) posttranscriptionally downregulates tumor suppressor Pdcd4 and stimulates invasion, intravasation and metastasis in colorectal cancer. Oncogene 2008, 27(15):2128-2136.

63. Wang CJ, Stratmann J, Zhou ZG, et al: Suppression of microRNA-31 increases sensitivity to 5-FU at an early stage, and affects cell migration and invasion in HCT-116 colon cancer cells. BMC Cancer 2010, 10:616.

64. Huang Z, Huang S, Wang Q, et al: MicroRNA-95 promotes cell proliferation and targets sorting Nexin 1 in human colorectal carcinoma. Cancer Res 2011, 71(7):2582-2589.

65. Tsang WP, Ng EK, Ng SS, et al: Oncofetal H19-derived miR-675 regulates tumor suppressor RB in human colorectal cancer. Carcinogenesis 2010, 31 (3):350-358.

66. Veedu RN, Wengel J: Locked nucleic acids: promising nucleic acid analogs for therapeutic applications. Chem Biodivers 2010, 7(3):536-542.

67. Valeri N, Gasparini P, Braconi C, et al: MicroRNA-21 induces resistance to 5fluorouracil by down-regulating human DNA MutS homolog 2 (hMSH2). Proc Natl Acad Sci U S A 2010, 107(49):21098-21103.

68. Kauppinen $\mathrm{S}$, Vester $\mathrm{B}$, Wengel J: Locked nucleic acid: high-affinity targeting of complementary RNA for RNomics. Handb Exp Pharmacol 2006, 173:405-422.

69. Ebert MS, Neilson JR, Sharp PA: MicroRNA sponges: competitive inhibitors of small RNAs in mammalian cells. Nat Methods 2007, 4(9):721-726.

70. Xiao J, Yang B, Lin H, et al: Novel approaches for gene-specific interference via manipulating actions of microRNAs: examination on the pacemaker channel genes HCN2 and HCN4. J Cell Physiol 2007, 212 (2):285-292.

71. Choi WY, Giraldez AJ, Schier AF: Target protectors reveal dampening and balancing of Nodal agonist and antagonist by miR-430. Science 2007, 318 (5848):271-274.

72. Gumireddy $K$, Young DD, Xiong $X$, et al: Small-molecule inhibitors of microrna miR-21 function. Angew Chem Int Ed Engl 2008, 47(39):7482-7484.

73. Soussi T, Béroud C: Assessing TP53 status in human tumours to evaluate clinical outcome. Nat Rev Cancer 2001, 1:233-240.

74. Soussi T, Asselain B, Hamroun D, et al: Meta-analysis of the p53 mutation database for mutant p53 biological activity reveals a methodologic bias in mutation detection. Clin Cancer Res 2006, 12(1):62-69.

75. Akao $Y$, Noguchi $S$, lio A, et al: Dysregulation of microRNA-34a expression causes drug-resistance to 5-FU in human colon cancer DLD-1 cells. Cancer Lett 2011, 300(2):197-204.

76. Mudduluru G, Ceppi P, Kumarswamy R, et al: Regulation of AxI receptor tyrosine kinase expression by miR-34a and miR-199a/b in solid cancer. Oncogene 2011, 30(25):2888-99.

77. Hermeking H: The miR-34 family in cancer and apoptosis. Cell Death Differ 2010, 17:193-199.

78. Cole KA, Attiyeh EF, Mosse YP, et al: A functional screen identifies miR-34a as a candidate neuroblastoma tumor suppressor gene. Mol Cancer Res 2008, 6:735-742.

79. Ng EK, Tsang WP, Ng SS, et al: MicroRNA-143 targets DNA methyltransferases 3A in colorectal cancer. Br J Cancer 2009, 101(4):699-706.

80. Nakagawa $Y$, linuma $M$, Naoe $T$, et al: Characterized mechanism of alphamangostin-induced cell death: caspase-independent apoptosis with release of endonuclease-G from mitochondria and increased miR-143 expression in human colorectal cancer DLD-1 cells. Bioorg Med Chem 2007, 15(16):5620-5628.

81. Hu G, Chen D, Li X, et al: miR-133b regulates the MET proto-oncogene and inhibits the growth of colorectal cancer cells in vitro and in vivo. Cancer Biol Ther 2010, 10(2):190-197.
82. Li LN, Zhang HD, Zhi R, et al: Down-regulation of some miRNAs by degrading their precursors contributes to anti-cancer effect of mistletoe lectin-I. Br J Pharmacol 2011, 162(2):349-364

83. Liu M, Lang N, Qiu M, et al: miR-137 targets Cdc42 expression, induces cell cycle G1 arrest and inhibits invasion in colorectal cancer cells. Int J Cancer 2011, 128(6):1269-1279.

84. Zhang J, Guo H, Zhang $H$, et al: Putative tumor suppressor miR-145 inhibits colon cancer cell growth by targeting oncogene Friend leukemia virus integration 1 gene. Cancer 2011, 117(1):86-95.

85. Shi B, Sepp-Lorenzino L, Prisco M, et al: Micro RNA 145 targets the insulin receptor substrate- 1 and inhibits the growth of colon cancer cells. J Biol Chem 2007, 282(45):32582-32590.

86. Liu M, Lang $\mathrm{N}$, Chen $\mathrm{X}$, et al: miR-185 targets RhoA and Cdc42 expression and inhibits the proliferation potential of human colorectal cells. Cancer Lett 2011, 301(2):151-160.

87. Boni V, Bitarte N, Cristobal l, et al: miR-192/miR-215 influence 5fluorouracil resistance through cell cycle-mediated mechanisms complementary to its post-transcriptional thymidilate synthase regulation. Mol Cancer Ther 2010, 9(8):2265-2275.

88. Liu $L, C h e n ~ L, X u Y$, et al: microRNA-195 promotes apoptosis and suppresses tumorigenicity of human colorectal cancer cells. Biochem Biophys Res Commun 2010, 400(2):236-240.

89. Schimanski CC, Frerichs K, Rahman F, et al: High miR-196a levels promote the oncogenic phenotype of colorectal cancer cells. World J Gastroenterol 2009, 15(17):2089-2096.

90. Nakano H, Miyazawa T, Kinoshita K, et al: Functional screening identifies a microRNA, miR-491 that induces apoptosis by targeting $\mathrm{Bcl}-\mathrm{X}(\mathrm{L})$ in colorectal cancer cells. Int J Cancer 2010, 127(5):1072-1080.

91. Kumar MS, Lu J, Mercer KL, et al: Impaired microRNA processing enhances cellular transformation and tumorigenesis. Nat Genet 2007, 39(5):673-677.

92. Merritt WM, Lin YG, Han LY, et al: Dicer, Drosha, and outcomes in patients with ovarian cancer. N Engl J Med 2008, 359(25):2641-2650.

93. Karube $\mathrm{Y}$, Tanaka H, Osada H, et al: Reduced expression of Dicer associated with poor prognosis in lung cancer patients. Cancer Sci 2005 96(2):111-115

94. Chiosea S, Jelezcova E, Chandran U, et al: Overexpression of Dicer in precursor lesions of lung adenocarcinoma. Cancer Res 2007, 67(5):2345-2350.

95. Gupta PB, Chaffer CL, Weinberg RA: Cancer stem cells: mirage or reality? Nat Med 2009, 15(9):1010-1012.

96. Matsui W, Wang Q, Barber JP, et al: Clonogenic multiple myeloma progenitors, stem cell properties, and drug resistance. Cancer Res 2008, 68(1):190-197.

97. Visvader JE, Lindeman GJ: Cancer stem cells in solid tumours: accumulating evidence and unresolved questions. Nat Rev Cancer 2008, 8 (10):755-768.

98. Gangaraju VK, Lin H: MicroRNAs: key regulators of stem cells. Nat Rev Mol Cell Biol 2009, 10(2):116-125.

99. Zhu R, Yang Y, Tian Y, et al: Ascl2 knockdown results in tumor growth arrest by miRNA-302b-related inhibition of colon cancer progenitor cells. PLoS One 2012, 7(2):e32170.

100. Wang Y, Medvid R, Melton C, et al: DGCR8 is essential for microRNA biogenesis and silencing of embryonic stem cell self renewal. Nat Genet 2007, 39:380-385

101. Kanellopoulou C, Muljo SA, Kung AL, et al: Dicer-deficient mouse embryonic stem cells are defective in differentiation and centromeric silencing. Genes 2005, 19(4):489-501.

102. Calabrese JM, Seila AC, Yeo GW, et al: RNA sequence analysis defines Dicer's role in mouse embryonic stem cells. Proc Natl Acad Sci USA 2004, 104(46):18097-18102.

doi:10.1186/1479-5876-10-128

Cite this article as: Aslam et al:: MicroRNA manipulation in colorectal cancer cells: from laboratory to clinical application. Journal of

Translational Medicine 2012 10:128. 